\title{
Memórias político-literárias em três versões
}

\author{
Nilze Paganini*
}

Entrevistas podem servir a vários propósitos. Da parte de quem entrevista, evidentemente são úteis para se obter novos dados, corroborar suposições, produzindo um documento comprobatório e assim por diante. Os entrevistadores tentam conduzir as interlocuções, direcionando-as para alcançar determinados objetivos. Contudo, boas entrevistas, no meu entendimento, são também aquelas que surpreendem os entrevistadores, por mais que eles tenham se preparado para a tarefa de indagar de forma eficaz e receber as respostas pretendidas.

As entrevistas que realizei com Affonso Ávila, Fábio Lucas e Rui Mourão sobre a revista Tendência, cumpriram todas estas funções. Elas possibilitaram a confirmação de algumas de minhas hipóteses sobre a forma de financiamento da revista, as relações de seus editores com o poder estadual e a orientação que deram às suas carreiras a partir do final dos anos de 1950, além de provar definitivamente a intenção e o tipo de diálogos ideológicos e literários realizados pelos intelectuais mineiros. Os três entrevistados reafirmaram o nacionalismo de Tendência e sua vinculação às ideas do Instituto Superior de Estudos Brasileiros - ISEB -, procuraram realçar o grande alcance da revista, assim como a importância dos debates empreendidos pela publicação e por seus membros, posicionando-se enfaticamente como defensores e/ou praticantes da experimentação poética e ficcional. Passagens saborosas também deram um toque de humor a certos trechos, como os casos narrados por Rui Mourão, dono de uma personalidade caracterizada, como ele mesmo admitiu, pelo otimismo.

Os leitores interessados em literatura, crítica literária ou história cultural mineira e brasileira podem encontrar, nas falas de Ávila, Lucas e Mourão, informações preciosas no que se refere ao seu fazer crítico e literário na segunda metade do século 20.

A primeira entrevista aconteceu com Rui Mourão. A segunda, com Affonso Ávila. Ambas em suas residências. A última, feita com Fábio Lucas, foi respondida por escrito. Este fato evidencia uma grande diferença entre elas. Enquanto as duas primeiras trazem a marca da oralidade, da informalidade, as respostas de Fábio Lucas mostram a utilização da língua padrão escrita e um maior controle das respostas. Justamente por ter tido mais tempo para refletir sobre o que declarar, medindo as palavras, ponderando as respostas, Lucas tentou, com mais ênfase do que os demais, fixar uma recepção favorável de Tendência e de seus editores para outras gerações de estudiosos. Pelo mesmo motivo, reformulações também estão presentes nos depoimentos de Ávila e

* Pontifícia Universidade Católica de Minas Gerais - PUC Minas 
Mourão. As entrevistas serviriam, talvez, para os entrevistados criarem, de maneira retocada, registros históricos referentes à revista e à atuação de seus membros. Afinal, as entrevistas foram realizadas 50 anos após o primeiro número de Tendência, lançada em agosto de 1957. A questão da memória e a reafirmação de uma identidade intelectual foram outros elementos que as entrevistas trouxeram para o primeiro plano de observação. Depois de tanto tempo, as lembranças tiveram de ser reavivadas e alguns lapsos fizeram com que se misturassem dados incorretos com outros verídicos. $\mathrm{O}$ desejo de reelaboração do passado, ligado à forma como gostariam de serem vistos enquanto intelectuais mineiros e brasileiros, foi um dos traços mais marcantes das falas dos três autores.

Se, por um lado, a entrevistadora tentou controlar o jogo de perguntas e respostas encaminhando-o para o que the interessava saber, também os entrevistados quiseram nortear as conversas para o que lhes convinha. É importante ressaltar que são narrativas sobre o início de suas carreiras crítico-literárias. Nelas, Fábio Lucas, Affonso Ávila e Rui Mourão reinterpretam o passado e reelaboram as suas imagens de intelectuais. Trata-se de um tipo de discurso sobre si próprios que pretende guiar a interpretação/recepção que o ouvinte/leitor fará destas narrativas. Ao trazer à memória os eventos de suas vidas, estes são organizados e explicados visando a criação de representações positivas. Relembrando o passado, os narradores/entrevistados transformam os fatos pretéritos e também as conexões desses acontecimentos com o presente e o futuro por meio de autonarrações. Os lapsos de memória são preenchidos por outros elementos e, o que se tem, é uma recriação da história, agora contada com acréscimos da experiência, da interpretação e de uma nova visão do mundo e dos fatos. Um exemplo muito claro disto são as avaliações de Tendência feitas por seus editores. As apreciações e rememorações do período de existência da revista foram influenciadas pelos discursos criados por eles posteriormente. Pude observar também que, em entrevistas e depoimentos realizados com Affonso Ávila, Rui Mourão e Fábio Lucas, após as declarações colhidas por mim, Tendência cresceu em importância nas narrativas autobiográficas traçadas por eles, voltando a ser mencionada com grande destaque. Assim, ganhando novas conotações, Tendência passou a ser referida como um marco em suas carreiras.

As características salientadas neste texto introdutório também foram um trabalho de reelaboração feito a partir da distância temporal e da memória da pesquisadora. Cabe agora aos futuros leitores, através da tentativa de entender o outro e enxergar o seu mundo, executar seleções de elementos das entrevistas que lhes parecerem mais significativos e interpretá-los. Como afirmei anteriormente, as entrevistas com Affonso Ávila, Fábio Lucas e Rui Mourão trazem em si informações relevantes para os estudiosos da literatura brasileira. 